DOI https://doi.org/10.18551/rjoas.2017-09.11

\title{
EVALUATION OF THE GOVERNANCE OF EXTERNAL SUPERVISORY INSTITUTIONS TOWARDS SOCIAL SECURITY AGENCY (BADAN PENYELENGGARA JAMINAN SOSIAL/BPJS) FOR HEALTHCARE
}

\author{
Dyani Dindha Ayu Mitra, Nuralam Inggang Perwangsa* \\ Faculty of Administrative Science, Universitas Brawijaya, Indonesia \\ *E-mail: ing.nuralam@ub.ac.id
}

\begin{abstract}
Since the formation of the Social Security Agency (Badan Penyelenggara Jaminan Sosial/BPJS) for Healthcare has found the public spotlight rising with its management; including the regulatory body BPJS for Healthcare activities. BPJS for Healthcare external supervisors such as DJSN, OJK, BPK are entities established according to the Law of the Republic of Indonesia 24 Year 2011. However, there are views on neutrality, independence, and supervisor capability. By using Soft System Methodology, this research invites us to understand the problem situation and what efforts should be taken in managing the complexity. This paper will analyze the co-operation with collaborative governance perspective as a cooperative approach in overseeing BPJS for Healthcare. The focus of this paper is in the stage of identifying a series of factors that are crucial within the collaborative process itself, which includes shared understanding as stated by Ansel \& Gash (2008) and Emerson \& Nabatchi (2015).
\end{abstract}

\section{KEY WORDS}

Soft system methodology, collaborative governance, external supervisors.

The Government of Indonesia seeks to improve health services for Indonesians, as evidenced by Law of Republic of Indonesia No. 24 of 2011 on Social Security Agency (Badan Penyelenggara Jaminan Sosial/BPJS) for Healthcare. Various challenges began to accompany the birth of Law No. 24 of 2011 , so that social security can be immediately felt by all the people. Based on observations on the implementation of BPJS for Healthcare, the Health Insurance policy in Indonesia faces problems that can be mapped using three levels of policy level (Bromley, 1989); policy level, the organizational level; and operational level.

In Organizational Level, there is factual problem ie the absence of regulation instrument formation of external BPJS for Healthcare Supervisory Board (DJSN, OJK, BPK) as mandated by the Law of Republic of Indonesia No. 24 Year 2011 regarding BPJS Article 39 paragraph (3). In the theory of collaborative governance, the absence of an ideal organizational setting is highlighted as a problem. This is because the organization BPJS is an entity in which all stakeholders in a state involved. Thus, stakeholders in other ways can also formulate, support, and become objects of strategic value management, corporate management, corporate goals (Freeman \& Reed, 1983); and be the responsibility of the company for the achievement of their satisfaction (Nuralam, 2016).

Collaborative Governance is the governance between institutions both state and nonstate agencies. This concept is born out of a society's view that the government has failed to represent the interests of society, and ultimately society has a bad view on the public sector and the legitimacy of the government (Hetherington, 2006). Osborne and Gaebler (1992) reveals the reason for the emergence of "reinvention" that transforms the "classical" bureaucracies that adopt organizations in the private and business sectors, so that it can change the response of the "classic" style of bureaucracy tends to be slow and unable to cope with competitive pressures

\section{LITERATURE REVIEW}

Public Policy and Its Formulation. Some scholars define Public Policy as a system 
consisting of measures, measurable regulations, laws, and financing priorities that focus on a particular topic by government agencies or their representatives. Public policy is generally embedded in constitutional board, legislative acts, and judicial decisions (Schuster II, 2008). Dye (1987) defines public policy as what the government does, how to do it, why it needs to be done and what difference it makes. Changes in public policy thus are dynamic in keeping with changes that are driven by changes in the environment outside and within the public organization.

Public policy making can be characterized as a dynamic, complex, and interactive system in which common problems are identified and resisted by creating new public policies or by reforming existing public policies (John, 1998). Common problems affecting public policy making can be from the economic, social, and political realms (Hill, 2005).

Policy formulation can not be separated from the management function inherent in the organization. Bromley (1989) captures this phenomenon by presenting a hierarchical policy theory that indicates the difference of content and policy context at each level within an organization. There are 3 (three) policy levels related to the hierarchy of policy making process, namely policy level, organizational level, and operational level.

Bromley's policy hierarchy is predominantly included in the context of public sector organizations. At the level of a country, Bromley's policy hierarchy provides a pretty clear picture of the policy level at each agency or institution in government. Applications of this theory can be adapted to the context of a policy and those with authority over the policy, whether at national, sectoral, or autonomous levels.

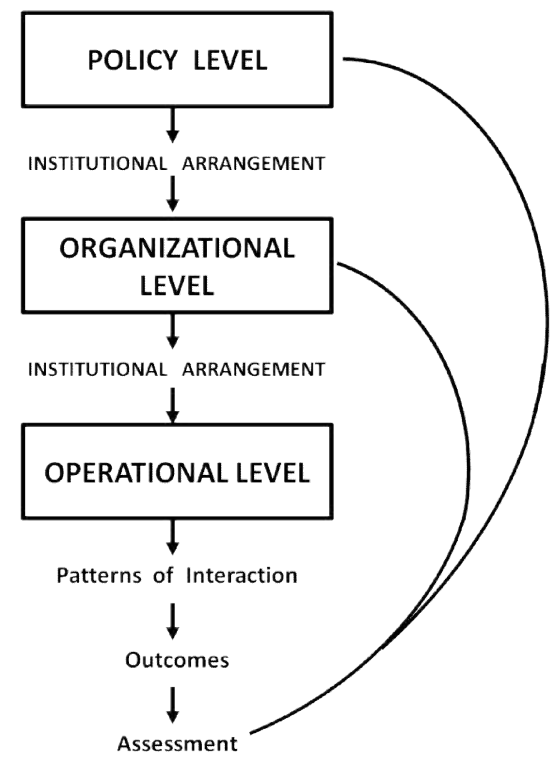

Figure 1 - Hierarchy of Policy Formulation Source: Bromley (1989)

Governance. The World Bank (1992) defines governance as a way in which power in economic development. Moreover, Neo and Chen (2007) define governance as the relationship between government and society that allows public policies and programs to be formulated, implemented and evaluated. By Hufty (2011) governance is the interaction and decision processes among actors involved in collective issues that lead to, strengthen, or build social norms and institutions. While Bevir (2013) defines it as all processes in government, whether committed by governments, markets or networks, whether within families, tribes, formal or informal organizations or territories and whether through organized laws, norms, powers or languages of society. In business and outsourcing relationships, governanc frameworks are built into relational contracts that foster long-term collaboration and innovation. Poor governance can lead to contract failure (Vitasek, 2011). Bouckaert and Pollit (2011) describe the concept of dangerous government, because it is considered only to 
overcome and contradict before, as well as public / private, or market bureaucracy. Osborne (2010) states governance needs to shift from traditional hierarchical organizational forms to network structures. In this sense requires a revision of relations between state and civil society in a more participatory direction.

Collaborative Governance. Collaborative governance was born out of a view from society that the government has failed to represent the interests of society, and ultimately the public has a bad view on the public sector and the legitimacy of the government (Hetherington, 2006). The concept of collaborative governance is possible because of dissatisfaction from the public regarding the performance of government organizations. The practice of collaborative governance is not only happening in the United States, but it has begun to be practiced in other countries (Freeman and Peck, 2006; Lee and Hague, 2006; Noble and Jones, 2006). The following are examples of collaborative governance practices in the United States: a) water resources management (Innes and Boher, 2003; Blomquist, et al., 2004); b) conservation of rare animals (Sabatier et al., 2005; Thomas, 2003).

Furthermore, Donahue (2004) considers that effective collaborative governance should provide new mechanisms for collaborative action determined by collaborative partners in line with their explicit and implied theory of theory to achieve the desired outcomes. The study conducted by Donahue and Zeckhauser (2011) reveals the role of government too often struggling with its inability to competence, will, and capacity in carrying out its mission. This is evidenced by the number of weak infrastructure, health services that are not balanced income and distribution, as well as tax leakage. Thus, Collaborative Governance becomes the main bargaining option to solve the problem by showing how governments at all levels can combine with the private sector in achieving public goals effectively.

The main purpose of the collaborative governance approach is to bring together several stakeholders together with the public agency and to engage in a deeper cooperation where there is a division of tasks and functions of each part with the same goals and ideology (shared vision among stakeholders, community and public agent) (Ansell and Gash, 2008). Emerson et al. (2012) have developed a less normative and less restrictive definition, as the processes and structures of the public policy of the decision making and management of public relations, the levels of government, and the public, private and civic spheres in order to carry out accomplished.

\section{METHODS OF RESEARCH}

Systems Thinking as an Approach. The purpose of the systems approach is to simplify our processes of thinking and managing complex facts (Senge, 1990). Systems thinking provides a selective way of dealing with the details that make possible complex thinking on the subject of transparency. Systems thinking guides understanding by looking at the relationship between elements to see the world (and make sense of it). The system approach begins with complex and uncertain situations. System language is about 'problem situation' rather than 'problem', and resolution (fixing situation) rather than solution (problem solving). Soft systems methodology (SSM) action research is in the position that the system is the epistemological construct of the real-world entities (Checkland, 1978). Given the background of SSM, Checkland and Poulter (2006) suggest that SSM developed is aptly used as an alternative study model, the social assessment model at the level of a group or organizational situation, ie action research.

Much of the literature on action research defines action research in the context of the learning process while doing something (learning by doing) and primarily for problem-solving purposes (Hardjosoekarto, 2012). According to O'Brien (1998), the problem-solving process with action research can be distinguished from the problem-solving process in the everyday sense, namely in its emphasis on scientific studies.

Soft System Methodology (SSM). This reasearch is using the Soft System Methodology (SSM) approach as a model to understand the problem situation and fixing the situation holistically. Soft Systems Methodology is a methodology based systems thinking 
and system concept that deals only with the human activity system (Hardjosoekarto, 2012) which consists of seven stages:

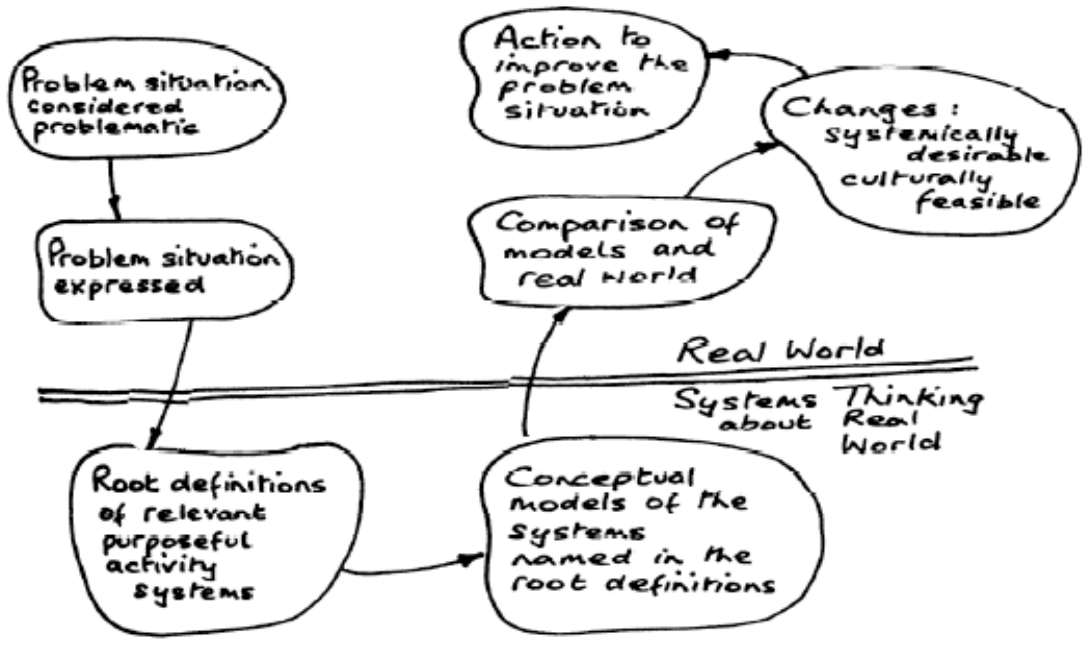

Figure 2 - Seven-Stage Model of SSM Source: Checkland and Scholes, 1990

This method consists of two parts of activity, namely 'real-world' and 'systems thinking', and seven stages, namely (1) problem situation considered problematic, (2) problem situation expressed, (3) root definition of relevant purposeful activity, (4) change systematically desireable, culturally feasible, and (7) action to improve the situation. Stages $1,2,5,6$ and 7 are real-world activities that contain problem situations, while stages 3 and 4 are systems thinking that may be involved in the situation of the problem, depending on the individual conducting the research.

\section{RESULTS AND DISCUSSION}

Stage 1 SSM: Problem Situation Considered Problematic. The BPJS Law states that BPJS is directly under the presidency and external supervision is conducted indirectly by BPK, DPR, and OJK and the National Social Security Council (DJSN) with all its limitations. On the other hand, the existence of DJSN assisting the president in the formulation of general policy is only to monitor and evaluate and synchronize the implementation of the National Social Security System (SJSN), conduct study and propose investment policy plus propose budget for beneficiaries. As an external supervisor, the DJSN has not performed its function effectively so it needs to be more empowered. The above explanation illustrates the vulnerability of direct supervision, requiring the management of BPJS to be performed by professionals with high integrity and proven "track record" of both the supervisory board and its directors. Such a large managed fund with much greater potential in the future may create a great temptation to deviate. Corruption can be done as easily as turning a hand without strict supervision by both internal (supervisory board and internal control unit) or external supervisor. Thus, the focus on integrity is mandatory and should be a major consideration. It is not just a matter of honesty to abstain from corruption, irregularities, and the like that must be prioritized, but also a commitment to efficiency and prohibited to disburse funds in accordance with one of the principles of social security.

The possibility of irregularities encountered by BPJS is quite diverse and vulnerable, so there needs to be a "good government" implementation which is periodically assessed by an independent consultant. It is therefore necessary that the supervisory board be proven to have practical experience in supervision, in addition to the integrity requirements. The representation of the tripartite element in the composition of the supervisory board is a "fatal weakness" in the provisions of the Act. Other considerations that govern BPJS well, rightly 
and rightly are the compliance with legislation and best practices in the provision of social security.

Stage 2 SSM: Problem Situation Expressed. Characteristics of SSM users, users will be observed through images and diagrams, known as rich picture - as well as making notes and writing narratives. Checkland (1990) states, this is because human events show the pageant of relationships, and images will better record relationships and connections than prose. Next, the researchers structured the problem that is linked to form the problem situation structure mapped in the form of rich picture. Rich picture will help researchers in doing research (Checkland and Poulter, 2006).

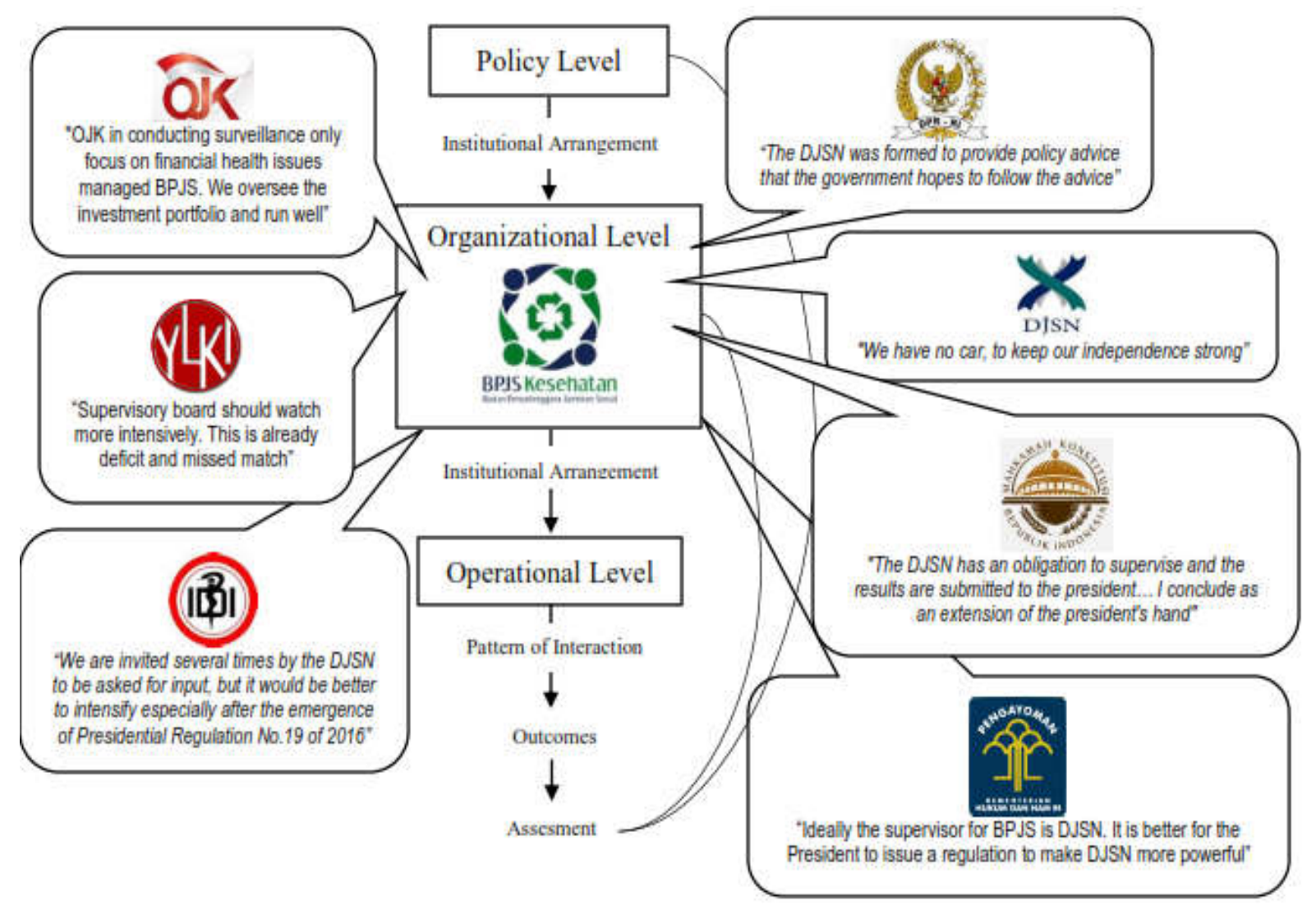

Figure 3 - Rich Picture in Organizational Level Source: Primary Data

Table 1 - CATWOE on RD

\begin{tabular}{cl}
\hline Customers & $\begin{array}{l}\text { President, House of Representatives, Regional Representative Council, Ministry of } \\
\text { Health, Ministry of Justice and Human Rights, Ministry of Finance, BPJS for Healthcare, } \\
\text { BPJS for Employment. }\end{array}$ \\
\hline Actors & DJSN, BPK, OJK \\
\hline Transformation & $\begin{array}{l}\text { Creating the External Monitoring Instrument BPJS for Healthcare Instrument (DJSN, OJK, } \\
\text { BPK); from the previous one that does not exist. } \\
\text { The establishment of the External Monitoring Instruments BPJS for Healthcare (DJSN, } \\
\text { OJK, BPK) is expected to clarify the authority of DJSN, OJK and BPK as external } \\
\text { Worldview } \\
\text { supervisors in assisting the President to formulate general policy and synchronize the } \\
\text { implementation of JKN system. }\end{array}$ \\
\hline Owner (s) & $\begin{array}{l}\text { BPJS for Healthcare, BPJS for Employment, DJSN, OJK, BPK } \\
\text { Environment }\end{array}$ \\
$\begin{array}{l}\text { Parties who do not want the occurrence of formal law and informal conventions in the } \\
\text { improvement of the Health Insurance System Policy }\end{array}$ \\
\hline
\end{tabular}

Stage 3 SSM: Root Definition (RD) of Relevant Purposeful Activity. RD is a relevant system concerning the system of problems studied. RD can also be interpreted as a brief verbal definition expression of the nature of the system deemed relevant to explore the 
problem situation. RD in this research contains the meaning of "System owned by External Supervisor of BPJS for Healthcare in formulating Regulation of Supervision through formal law in formulation of policies on BPJS Health External Governance Monitoring Instrument (DJSN, OJK, BPK) in order to guarantee achievement of collaborative governance of Indonesia's Health Insurance System".

Stage 4 SSM: Conceptual Models of the Systems Named in the Root Definition. In making the $\mathrm{CM}$ in each $\mathrm{RD}$ activity, it is analyzed using the elements of collaborative governance found in Emerson \& Nabatchi (2015).

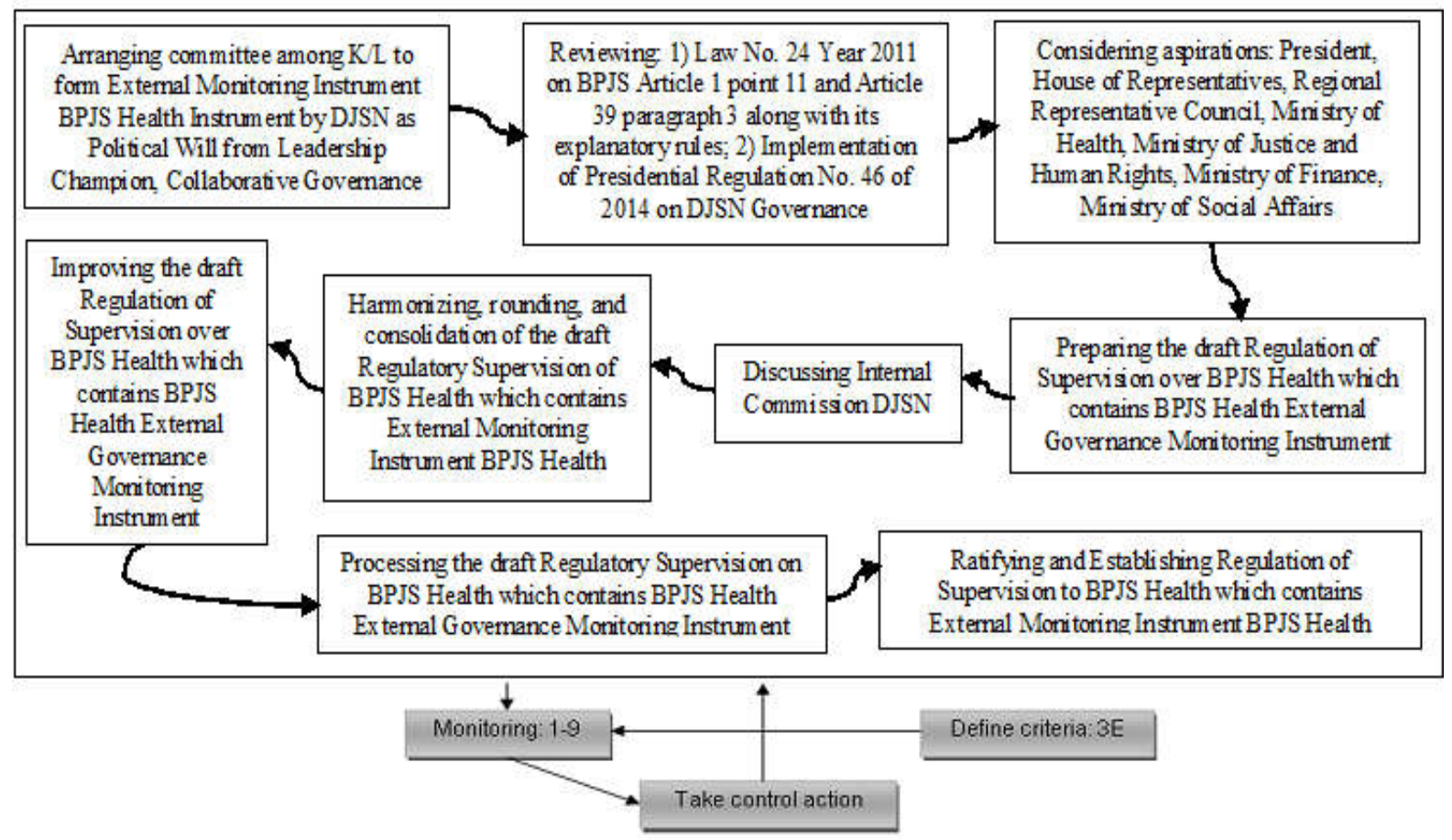

Figure 4 - Conceptual model at Organizational Level Effective.

The success of CM can be measured through three criteria: Efication, Efficiency, and

\begin{tabular}{cl}
\hline \multirow{2}{*}{ Efication } & $\begin{array}{l}\text { The existence of formal law and informal convention in forming Regulation of Supervision to } \\
\text { BPJS for Healthcare which contains External Monitoring Instrument BPJS for Healthcare } \\
\text { (DJSN, OJK, BPK) as mandated by Law of Republic of Indonesia Number } 24 \text { Year } 2011 \\
\text { regarding BPJS. }\end{array}$ \\
\hline Efficiency & Use the minimum resources (financial and time) \\
\hline \multirow{3}{*}{ Effective } & $\begin{array}{l}\text { Establishment of Supervision Regulation on BPJS for Healthcare which contains External } \\
\text { Monitoring Instrument BPJS for Healthcare (DJSN, OJK, BPK) as mandated by the Law of the } \\
\text { Republic of Indonesia Number 24 Year 2011 on BPJS. }\end{array}$ \\
\hline
\end{tabular}

Stage 5 SSM: Comparison of Models and Real World. This activity aims to answer the question of whether the model as an intellectual tool is relevant to the real research problem (Checkland, 1999); by means of Informal Discussion, Formal Discussion, Screenplay Writing, Real World Model Modeling Checkland and Poulter (2006) and Checkland (1999).

Stage 6 SSM: Systematically Desirable and Culturally Feasible. After conducting discussions and researches to compare conceptual models with perceived reality, the next step is to formulate recommendations for any changes or actions needed to address the problems. The recommendations are usually described as "systematically desirable" and "culturally feasible" (culturally feasible to do in the real world) to support the desired change of theoretical research practice or research interest. So that in the end will be gained knowledge (understanding) about Collaborative Governance best practice in JKN program become lesson learned. 
Table 2 - Comparison Conceptual Model with Real World

\begin{tabular}{|c|c|c|c|c|c|}
\hline No. & Activity in the Model & Exists? & Who? & $\begin{array}{l}\text { Good } \\
\text { / bad? }\end{array}$ & Alternatives? \\
\hline 1 & $\begin{array}{l}\text { Arranging committee among Ministry / } \\
\text { Institution to form External Monitoring } \\
\text { Instrument BPJS for Healthcare } \\
\text { Instrument by DJSN as Political Will from } \\
\text { Leadership Champion, Collaborative } \\
\text { Governance }\end{array}$ & No & DJSN & Good & $\begin{array}{l}\text { Collaboration with DPR RI, DPD } \\
\text { RI, and Ministry of Health }\end{array}$ \\
\hline 2 & $\begin{array}{l}\text { Reviewing: 1) Law No. } 24 \text { Year } 2011 \text { on } \\
\text { BPJS Article } 1 \text { point } 11 \text { and Article } 39 \\
\text { paragraph } 3 \text { along with its explanatory } \\
\text { rules; 2) Implementation of Presidential } \\
\text { Regulation No. } 46 \text { of } 2014 \text { on DJSN } \\
\text { Governance }\end{array}$ & No & DJSN & Good & $\begin{array}{l}\text { Collaboration with Ministry of } \\
\text { Labor, Ministry of PAN-RB, } \\
\text { Labor Practitioner, Researcher, } \\
\text { and Academician }\end{array}$ \\
\hline 3 & $\begin{array}{l}\text { Considering aspirations: President, House } \\
\text { of Representatives, Regional } \\
\text { Representative Council, Ministry of } \\
\text { Health, Ministry of Justice and Human } \\
\text { Rights, Ministry of Finance, Ministry of } \\
\text { Social Affairs }\end{array}$ & No & $\begin{array}{l}\text { DJSN } \\
\text { and } \\
\text { BPJS }\end{array}$ & Good & $\begin{array}{l}\text { Collaboration with Ministry of } \\
\text { Labor, Ministry of PAN-RB, } \\
\text { Labor Practitioner, Researcher, } \\
\text { and Academician }\end{array}$ \\
\hline 4 & $\begin{array}{l}\text { Preparing the draft Regulation of } \\
\text { Supervision over BPJS for Healthcare } \\
\text { which contains BPJS for Healthcare } \\
\text { External Governance } \\
\text { Instrument }\end{array}$ & No & DJSN & Good & $\begin{array}{l}\text { Collaboration with House of } \\
\text { Representatives, Regional } \\
\text { Representative Council, Ministry } \\
\text { of Health, and BPJS, } \\
\text { Researcher, and Academics }\end{array}$ \\
\hline 5 & Discussing Internal Commission DJSN & No & DJSN & Good & $\begin{array}{l}\text { Collaboration with House of } \\
\text { Representatives, Regional } \\
\text { Representative Council, Ministry } \\
\text { of Health, and BPJS, } \\
\text { Researcher, and Academics }\end{array}$ \\
\hline 6 & $\begin{array}{l}\text { Harmonizing, rounding, and consolidation } \\
\text { of the draft Regulatory Supervision of } \\
\text { BPJS for Healthcare which contains } \\
\text { External Monitoring Instrument BPJS for } \\
\text { Healthcare }\end{array}$ & No & DJSN & Good & $\begin{array}{l}\text { Consultation with House of } \\
\text { Representatives, } \\
\text { Representative Council, Ministry } \\
\text { of Justice and Human Rights }\end{array}$ \\
\hline 7 & $\begin{array}{l}\text { Improving the draft Regulation of } \\
\text { Supervision over BPJS for Healthcare } \\
\text { which contains BPJS for Healthcare } \\
\text { External Governance } \\
\text { Instrument }\end{array}$ & No & DJSN & Good & $\begin{array}{l}\text { Consultation with House of } \\
\text { Representatives, } \\
\text { Representative Council, Ministry } \\
\text { of Justice and Human Rights }\end{array}$ \\
\hline 8 & 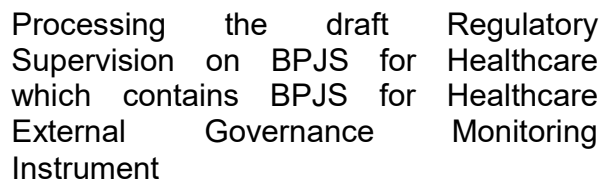 & No & DJSN & Good & $\begin{array}{l}\text { Consultation with House of } \\
\text { Representatives, } \\
\text { Representative Council, Ministry } \\
\text { of Justice and Human Rights, } \\
\text { BPJS }\end{array}$ \\
\hline 9 & $\begin{array}{l}\text { Ratifying and Establishing Regulation of } \\
\text { Supervision to BPJS for Healthcare which } \\
\text { contains External Monitoring Instrument } \\
\text { BPJS for Healthcare }\end{array}$ & No & DJSN & Good & $\begin{array}{l}\text { Socialization by House of } \\
\text { Representatives, Ministry of } \\
\text { Health, Ministry of Manpower }\end{array}$ \\
\hline
\end{tabular}

Source: Adapted from Checkland and Scholes (1990).

Table 3 - System Changes

\begin{tabular}{|c|c|c|}
\hline Name of RD & Systematically Desirable? & Culturally Feasible? \\
\hline The Establish an external & Yes, through the preparation of external BPJS & representing \\
\hline BPJS for Healthcare & Healthcare Monitoring Supervisory & accommodation \\
\hline Monitoring Agency (DJSN, & instruments (DJSN, OJK, BPK) supplen & interests of \\
\hline OJK, BPK) instrument in & supervisory procedures that have been & Healthcare External \\
\hline accordance with the Law & out so far, it is expected to clarify the a & Governance \\
\hline of the Republic of & of BPJS for Healthcare external & accordance with the mandate of the \\
\hline Indonesia Number 24 Year & (DJSN, OJK, BPK) as external supervision in & Law of the Republic of Indonesia \\
\hline 2011 regarding BPJS & assisting President to formulate general & Number 24 Year 2011 on BPJS \\
\hline Article 39 paragraph (3) & $\begin{array}{l}\text { policies and synchronize the implementation of } \\
\text { the national social security system }\end{array}$ & Article 39 paragraph (3) \\
\hline
\end{tabular}

Source: Adoption of Checkland and Scholes, 1990. 
Stage 7 SSM: Action to Improve the Situation. The action to improve the situation stage is an action to improve, refine, and change the problematic situation. This stage is the "end" stage of SSM. Given that since the beginning of the SSM process has involved both Clients and Owners (of the issues addressed), and considering that the process is a learning system (learning systems), then by itself there is no resistance to take action based on the proposed action steps that have been formulated (Hardjosoekarto 2012). This stage also asks whether posible action can be done in this research to change the system.

Table 4 - Possible Action on the system

Possible Action

Yes, by representing an accommodation of the different interests of stakeholders on BPJS for Healthcare external Monitoring instruments, so BPJS for Healthcare can organize a national social security system based on the following principles: a. mutual cooperation; b. non-profit; c. openness; d. caution; e. accountability; f. portability; g. membership is mandatory; h. trust fund; and i. the results of the management of the Social Security Fund shall be used wholly for the development of the program and for the greatest interest of the Participant; as mandated by the Law of the Republic of Indonesia Number 24 Year 2011 on BPJS Article 39 paragraph (3)

\section{CONCLUSION}

BPJS for Healthcare management is still seen partially and non-holistic. It was caught the problems in the management of BPJS for Healthcare especially external supervision as a systemic problem and needed to be solved in a non-linear way. Studies conducted at the organizational level (DJSN, Supervisory Board, and BPJS for Healthcare using collaborative governance theory emphasizes the collaboration made by the government with other governmental or non-governmental organizations for the success of the program being run. In general, the research conclusions focus on collaborative governance interwoven among government agencies; and also involves non-governmental organizations acting as overseers of BPJS for Healthcare organizations.

In Organizational Level JKN's policy practice in Indonesia using collaborative governance approach, managed by BPJS for Healthcare is still far from ideal value. This can be seen from the lack of Principled Engagement and Joint Capacity for Action among stakeholders. Strengthening external and internal BPJS for Healthcare supervisory rules is required to perform program control functions; and the success of the JKN program.

By system, the improvement of BPJS for Healthcare management especially external supervision can be done through several steps so that action implementation can be done well. In principle, there needs to be a system that governs the establishment of BPJS for Healthcare external regulatory instruments, so that BPJS for Healthcare can organize a national social security system.

It is concluded that there is one value that is not owned in the theory of collaborative governance, namely political will. After deepening the problems SJSN, JKN, Operations BPJS for Healthcare, and Jamkesmas; found that leadership champion will not develop without political will. It is interpreted as a dynamic or dynamic process of collaboration in implementing the JKN program at every level of policy (Bromley, 1989) conducted between government organizations, or government organizations with the community.

\section{ACKNOWLEDGMENTS}

This research is conducted by a joint research team organized by Faculty of Administrative Science (FIA) and Research Institutions and Community Service (LPPM), Universitas Brawijaya. Members of the team are Inggang Perwangsa Nuralam (Faculty of Administrative Science) and Dindha Ayu Mitra Dyani (Faculty of Administrative Science). The research team expresses their gratitude to the Director of Research Institutions and Community Service (LPPM), Universitas Brawijaya who grants a collaborative Research Grant for budget year 2017. 


\section{REFERENCES}

1. Ansell, Chris \&, Alison Gash. (2008). "Collaborative Governance in Theory and Practice". Journal of Public Administration Research and Theory. 18 (4): 544.

2. Bevir, Mark. (2013). Governance: A very short introduction. Oxford, UK: Oxford University Press.

3. Blomquist, W., E. Schlager and T. Heikkila. (2004). Common Waters, Diverging Streams: Linking Institutions and Water Management in Arizona, California, and Colorado. Washington, DC: Resources for the Future.

4. Bouckaert, Geert and Christhoper Pollit. (2011). Public Management Reform Oxford University Press

5. Bromley, Daniel W. (1989). Economic Interest and Institutions: The Conceptual Foundations of Public Policy. New York: Basil Blackwell.

6. Checkland, P. (1978). "The Origins and Nature of 'Hard' Systems Thinking." Journal of Applied Systems Analysis 5: 99-110.

7. Checkland, P. (1999). Systems thinking. Rethinking management information systems, 45-56.

8. Checkland, Peter, \& John Poulter. (2006). Learning for Action: A Short Definitive Account of Soft Systems Methodology and its use for Practitioners, Teachers, and Students. England: John Wiley \& Sons Ltd.

9. Checkland, Peter, \& Scholes. (1990). Soft Systems Methodology in Action. England: John Wiley \& Sons Ltd.

10. Donahue, John D., and Richard J. Zeckhauser. (2011). Collaborative Governance: private roles for public goals in turbulent times. United Kingdom: Princeton University Press.

11. Donahue, John. (2004). On collaborative governance. Working Paper \#2. CSRI. http://www.hks.harvard.edu/mrcbg/CSRI/publications/workingpaper_2_donahue.pdf.

12. Dye, Thomas R. (1987). Understanding Public Policy. Prentice Hall Inc., New Jersey.

13. Emerson, Kirk, Tina Nabatchi, Stephen Balogh. (2012). "An Integrative Framework for Collaborative Governance". Journal of Public Administration Research and Theory. 22 (1): 1-29.

14. Emerson, Kirk., and Tina Nabatchi. (2015). Collaborative Governance Regimes. Washington DC: Georgetown University Press.

15. Freeman, R. E., \& Reed, D. L. (1983). Stockholders and stakeholders: A new perspective on corporate governance. California management review, 25(3), 88-106.

16. Freeman, Tim., and Edward Peck. (2006). Evaluating partnerships: a case study of integrated specialist mental health services. Health \& Social Care in the Community. Volume 14, Issue 5, pages 408-417, September 2006

17. Hardjosoekarto, Sudarsono. (2012). Soft System Methodology (Metode Serba Sistem Lunak). UI Press, Jakarta

18. Hetherington, M. J. (2006). Why Trust Matters: Declining Political Trust and the Demise of American Liberalism. Princeton, NJ: Princeton University Press.

19. Hill, Michael. (2005). Public Policy Process. London: Pearson.

20. Hufty, Marc (2011). "Investigating Policy Processes: The Governance Analytical Framework (GAF). In: Wiesmann, U., Hurni, H., et al. eds. Research for Sustainable Development: Foundations, Experiences, and Perspectives.". Bern: Geographica Bernensia: 403-424.

21. Innes, J. E. and D. E. Boher. (2003). Collaborative policymaking: governance through dialogue. In Deliberative Policy Analysis: Understanding Governance in the Network Society. Edited by M. Hajer and H. Wagenaar. New York, NY: Cambridge University Press.

22. John, Peter. (1998). Analysing Public Policy. London: Routledge.

23. Lee, E. W. Y. and M. S. Haque. (2006). The New Public Management Reform and Governance in Asian NICs: A Comparison of Hong Kong and Singapore. Governance, 19(4): 531-698. 
24. Neo, Boon Siong and Geraldine Chen. (2007). Dynamic Governance; Embedding Culture, Capabilities and Change in Singapore. Singapore: World Scientific Publishing Co. Pte. Ltd

25. Noble, G. and R. Jones. (2006). The Role of Boundary Spanning Managers in the Establishment of Public-Private Partnerships. Public Administration 84(4): 817-1122.

26. O'Brien, Rory. (1998). An Overview of the Methodological Approach of Action Research. http://www.web.ca/-robien/papers/artifinal.html

27. Osborne, David., and Ted Gaebler. (1992). How the Entrepreneurial Spirit is Transforming the Public Sector. Reading, MA: Addison-Wesley.

28. Osborne, Stephen P. (2010). The New Public Governance?: Emerging Perspectives on the Theory and Practice of Public Governance. UK: Routledge.

29. Nuralam, I. P. (2016). Creating Customer Relationship Management Based On Islamic Values: A Case Study Of Pt. Bank Muamalat Indonesia Tbk. Russian Journal of Agricultural and Socio-Economic Sciences, 58(10).

30. Sabatier, P. A., W. Focht, M. Lubell, Z. Trachtenberg, A. Vedlitz and M. Matlock. (2005). Swimming Upstream: Collaborative Approaches to Watershed Management. Cambridge, MA: The MIT Press.

31. Schuster II, W. Michael. (2008). For the Greater Good: The Use of Public Policy Considerations in Confirming Chapter 11 Plans of Reorganization. Houston Law Review, Vol. 46, p. 467, 2009

32. Senge, Peter. M. (1990). The Fifth Discipline: The Art and Practice of The Learning Organization. New York: Divison of Bantam Doubleday Dell Publishing Group.Inc

33. Thomas, C. W. (2003). Bureaucratic Landscapes: Interagency Cooperation and the Preservation of Biodiversity. Cambridge, MA: MIT Press.

34. Vitasek, Kate; et al. (2011). The Vested Outsourcing Manual (1st ed.). New York: Palgrave Macmillan. ISBN 0230112684.

35. World Bank. (1992). Governance and development. Washington, DC: The World Bank.

(c) 2017 by the authors. Licensee RJOAS, Orel, Russia. This article is an open access article distributed under the terms and conditions of the Creative Commons Attribution (CC BY) license: http://creativecommons.org/licenses/by/4.0/ 